\title{
Antioxidant activity, total phenolic and flavonoid content of several indigenous species of ferns in East Kalimantan, Indonesia
}

\author{
HENNY NURHASNAWATI ${ }^{1, \vartheta}$, REKSI SUNDU $^{1}$, SAPRI $^{1}$, RISA SUPRININGRUM ${ }^{1}$, HARLINDA KUSPRADINI $^{2}$, \\ ENOS TANGKE ARUNG \\ ${ }^{1}$ Akademi Farmasi Samarinda. Jl. A. Wahab Syahrani 226, Samarinda 75124, East Kalimantan, Indonesia. \\ Tel./fax. +62-541-7777363, `email: henny.nurhasnawati@gmail.com \\ ${ }^{2}$ Department of Forest Product Technology, Faculty of Forestry, Universitas Mulawarman. Jl. Ki Hajar Dewantara, Kampus Gunung Kelua, Samarinda \\ 75123, East Kalimantan, Indonesia. Tel./fax.: +62-541-735379, ${ }^{\text {}}$ email: tangkearung@ yahoo.com
}

Manuscript received: 7 December 2018. Revision accepted: 30 January 2019.

\begin{abstract}
Nurhasnawati H, Sundu R, Sapri, Supriningrum R, Kuspradini H, Arung ET. 2019. Antioxidant activity, total phenolic and flavonoid content of several indigenous species of ferns in East Kalimantan, Indonesia. Biodiversitas 20: 576-580. This study aimed to determine the total phenolic and flavonoids content and antioxidant activity of ethanol extract of several indigenous species of ferns in East Kalimantan. Total phenolic content was determined by Folin-Ciocalteau method and flavonoid content was measured by colorimetric method. Antioxidant activity was evaluated by DPPH (2,2-diphenyl-1-picrylhydrazyl) method. The result of photochemical screening indicated that the leaves of Plagiogyria pycnophylla, Plagiogyria glauca, and Stenochlaena palustris contained alkaloid, flavonoid, tannin, saponin, and steroid while Acrostichum aureum contained flavonoid, tannin, saponin and steroid. The result showed extract Acrostichum aureum had the highest total phenolic content $\left(366.4573 \pm 2.2117 \mathrm{mg}\right.$ GAE.g $\left.\mathrm{g}^{-1}\right)$, flavonoid content $(228.6087 \pm$ $2.2548 \mathrm{mg} \mathrm{QE} . \mathrm{g}^{-1}$ ), and very strong antioxidant activity with $\mathrm{IC}_{50}$ value $29.5303 \mathrm{ppm}$. There is positive correlation between total phenolic content, flavonoid with antioxidant activity.
\end{abstract}

Keywords: ferns, antioxidant, DPPH, total phenolic, flavonoid

\section{INTRODUCTION}

Ferns are vascular plants that are widespread throughout Indonesia. There are approximately 12,000 species of ferns around the world and 1,300 of them are found in Indonesia (Wang 2017; Imaniar 2017). Local people use ferns for food, as ornamental plants and traditional medicine (Ridianingsih et al. 2017). Plagiogyria pycnophylla (Kunze) Mett. and Plagiogyria glauca (Blume) Mett. are species of ferns that can be found in West Kutai District in East Kalimantan. Empirically, the Dayak Benuaq ethnic group uses the leaves and rhizomes of those plants as anti-cancer, especially breast cancer and antitoxin. The rhizome of Acrostichum aureum L. is used to treat snake bites, wounds and pustules while the leaves are used to stop bleeding (Khan et al. 2013). Empirically, the Dayak people use the leaves of Stenochlaena palustris (Burm. F.) Bedd. for face powder.

A number of diseases are caused by excessive oxidation in the body which increases the amount of free radicals. Free radical is a substance or molecule having one or more unpaired electrons in its outer orbit (Phaniendra 2015). Free radicals are continuously produced endogenously by human body through normal metabolic processes, inflammation and malnutrition. Apart from those, free radical can also be derived exogenously through pollution, ultraviolet radiation and cigarette smoke.

Antioxidant is a substance that provides protection from oxidation reaction (Cross et al. 1994). The use of synthetic antioxidants as the source of exogenous antioxidants might have side effects, so natural antioxidants are a necessary alternative. The choice and availability of natural antioxidant are still limited so that research on natural antioxidant becomes a trend among researchers (Sayuti and Yenrina 2015).

In this study, we determine the total phenolic, flavonoid content and the evaluation of antioxidant activity of several indigenous species of ferns in East Kalimantan as preliminary study considering the potential of ferns as source of medicine and cosmetics.

\section{MATERIALS AND METHODS}

\section{Collection and ferns identification}

Several species of ferns that have been used empirically for medicines and cosmetics were collected from West Kutai District and Samarinda City, East Kalimantan, Indonesia during October-December 2017. Identification of ferns was carried out at the Plant Anatomy and Systematics Laboratory of the Faculty of Mathematics and Natural Sciences in Mulawarman University, Samarinda, Indonesia. Species of ferns used in this study were: Plagiogyria pycnophylla (Kunze) Mett.; Plagiogyria glauca (Blume) Mett.; Acrostichum aureum L. and Stenochlaena palustris (Burm. F.) Bedd.

\section{Chemical reagents}

The reagents used were distilled water, acetic anhydride, gallic acid, aluminum chloride, hydrochloric 
acid, sulfuric acid, amyl alcohol, iron (III) chloride, dimethyl sulfoxide (DMSO), 2,2-diphenyl-1-picrylhydrazyl (DPPH), 70\% ethanol, ethyl acetate, Folin-Ciocalteau, chloroform, quercetin, sodium hydroxide, sodium nitrite, $n$ hexane, Bouchard reagent, Dragendorf reagent, Mayer reagent, magnesium powder.

\section{Extraction and phytochemical screening}

Ferns were sorted, washed, drained, air-dried in the open air and protected from direct sunlight exposure due to in the humid condition, fungi will easily grow. Dried samples were ground using a blender and sieved with a 60 mesh sieve. Weighed as much as $250 \mathrm{~g}$ of simplicia soaked in ethanol solvent by maceration extraction method. Phytochemical screening was conducted using procedures described by Marjoni (2016) and Harborne (1987) to determine the presence of alkaloid, flavonoid, tannin, saponin, and steroid; that are described below.

Alkaloid. The sample was weighed as much as 0.5 grams, $1 \mathrm{ml}$ of $2 \mathrm{~N}$ hydrochloric acid and $9 \mathrm{ml}$ of distilled water were added, heated over water bath for 2 minutes, cooled and then filtered. The filtrate was used for the following test: 3 drops of filtrate were taken to add 2 drops of Mayer reagent (to produce white/yellow precipitate), Bouchardat reagent (dark brown precipitate), Dragendorf reagent (red brick precipitate). If two of the three tests above give a positive result, then the extract contains an alkaloid.

Flavonoids. A total of 0.5 grams of sample was extracted using $10 \mathrm{~mL}$ of distilled water, filtered, taken 5 $\mathrm{ml}$ then added $0.1 \mathrm{~g}$ of $\mathrm{Mg}$ powder, $1 \mathrm{~mL}$ of concentrated $\mathrm{HCl}$ and $2 \mathrm{~mL}$ of amyl alcohol, shaken and allowed to separate. Flavonoids are positive if there is red, yellow, orange in the amyl alcohol layer.

Tanin. A total of 0.5 grams of sample was extracted using $10 \mathrm{~mL}$ of distilled water. The extraction results are filtered then the filtrate obtained is diluted with distilled water until it is colorless. Taken as much as $2 \mathrm{~mL}$, then added with 1-2 drops of $\mathrm{FeCl}_{3} 1 \%$. Blue or blackish green occurs indicating the presence of tannins.

Saponin. A total of 0.5 grams of sample is put into a test tube and added $10 \mathrm{~mL}$ of hot distilled water, cooled then shaken vigorously for 10 seconds, foam or foam is formed which for no less than 10 minutes is $1-10 \mathrm{~cm}$ high. $1 \mathrm{HCl} 2 \mathrm{~N}$ was added, if the froth did not disappear indicating saponins.

Steroids/terpenoids. A sample of 1 gram is macerated with $20 \mathrm{~mL} n$-hexane for 2 hours, then filtered. The filtrate is evaporated over water. At the residue, 2 drops of anhydrous acetic acid were added and 1 drop of concentrated sulfuric acid. A purple or red color indicates a terpenoid, then turns blue-green indicating steroids.

\section{Determination of total phenolic}

Total phenolic content in each extract was evaluated using Folin-Ciocalteau (FC) method, according to the method by Bajalan et al. (2017) and Adesegun et al. (2007) research with slight modifications. This method based on the inhibition power of phenolic hydroxyl group. Phenolic compounds react with Folin-Ciocalteau reagent. The principle of Folin-Ciocalteau method was the formation of blue-color complex compound (Alfian and Susanti 2012).

\section{Making a calibration curve}

Gallic acid solution with a concentration of $200 \mathrm{mg} / \mathrm{L}$ ( $5 \mathrm{mg}$ gallic acid was made in $25 \mathrm{ml}$ of distilled water) was then made into a series of solutions with a concentration of $12.5 ; 25 ; 50 ; 100$ and $200 \mathrm{mg} / \mathrm{L}$ (or ppm) of $10 \mathrm{ml}$ each. Then $0.1 \mathrm{ml}$ of each of the standard gallic acid series solution was taken and added $2 \mathrm{ml}$ of $\mathrm{Na}_{2} \mathrm{CO}_{3}$, left for 5 minutes. Next, $1 \mathrm{ml}$ of Folin Ciocalteau solution was diluted with distilled water $(1: 10)$ and incubated for 30 minutes. The absorbance is measured at a wavelength of $780 \mathrm{~nm}$ against reagent blank for each series of standard solutions so that a curve with a linear regression equation is obtained $(y=b x+a)$.

\section{Measurement of absorbance of the sample}

A sample solution of $1000 \mathrm{mg} / \mathrm{L}$ was made $(10 \mathrm{mg}$ extract in $1 \mathrm{ml}$ DMSO, the volume was sufficient to $10 \mathrm{ml}$ with distilled water), then $0.1 \mathrm{ml}$ was taken and added $\mathrm{Na}_{2} \mathrm{CO}_{3}$, left for 5 minutes. Then added $1 \mathrm{ml}$ of Folin Ciocalteau solution and incubate for 30 minutes. The absorbance is measured at a wavelength of $780 \mathrm{~nm}$ against reagent blank.

\section{Calculation of total phenolic levels}

The sample absorbance value is entered as the y value in the linear regression equation, so the value of $\mathrm{x}$ can be determined. Total phenolic levels are calculated using the following formula: $\mathrm{TPC}=(\mathrm{C} . \mathrm{V}) / \mathrm{W}$; where $\mathrm{TPC}=$ total phenolic content (mg. $\mathrm{g}^{-1}$ extract); $\mathrm{C}=$ concentration of sample established from the calibration curve $(\mathrm{mg} / \mathrm{L}) ; \mathrm{V}=$ volume of sample solution (L); W = weight of ethanolic plant extract $(\mathrm{g})$. Total phenolic content was expressed as mg gallic acid equivalent per gram extract (mg GAE. $\left.{ }^{-1}\right)$.

\section{Determination of flavonoid content}

The determination of flavonoid content in extract was done using colorimetric method, according to method by Chandra et al. (2014) and Bajalan et al. (2017).

\section{Making a calibration curve}

Quercetin solution with a concentration of $200 \mathrm{mg} / \mathrm{L}$ (5 $\mathrm{mg}$ in $1 \mathrm{ml}$ DMSO, volume up to $25 \mathrm{ml}$ with ethanol) was then made into a series of solutions with a concentration of $12.5 ; 25 ; 50 ; 100$ and $200 \mathrm{mg} / \mathrm{L}$ (or ppm) of $10 \mathrm{ml}$ each. Then $0.5 \mathrm{ml}$ were taken from the standard quercetin series solution, added $0.15 \mathrm{ml} 15 \% \mathrm{NaNO}_{2}$, left for 6 minutes. Then added $0.15 \mathrm{ml}$ of $\mathrm{AlCl}_{3} 10 \%$ and incubated for 60 minutes. Then added $2 \mathrm{ml}$ of $4 \% \mathrm{NaOH}, 2 \mathrm{ml}$ of distilled water and left for 15 minutes. The absorbance is measured at a wavelength of $420 \mathrm{~nm}$ against reagent blank for each standard solution series to obtain a curve with a linear regression equation is obtained $(y=b x+a)$.

\section{Measurement of absorbance of the sample}

A sample solution of $1000 \mathrm{mg} / \mathrm{L}$ was made $(10 \mathrm{mg}$ of extract in $1 \mathrm{ml}$ of DMSO, sufficient volume of $10 \mathrm{ml}$ with aquades), $0.5 \mathrm{ml}$ was taken added $0.15 \mathrm{ml}$ of $15 \% \mathrm{NaNO}_{2}$, 
left for 6 minutes. Then added $0.15 \mathrm{ml}$ of $\mathrm{AlCl}_{3} 10 \%$ and incubated for 60 minutes. Then added $2 \mathrm{ml}$ of $4 \% \mathrm{NaOH}, 2$ $\mathrm{ml}$ of distilled water and left for 15 minutes. The absorbance is measured at a wavelength of $420 \mathrm{~nm}$ against reagent blank.

\section{Calculation of flavonoid levels}

The sample absorbance value is entered as the $y$ value in the straight line equation, so the value of $\mathrm{x}$ can be determined. Total phenolic levels are calculated using the formula: $\mathrm{FC}=(\mathrm{C} . \mathrm{V}) / \mathrm{W}$; where $\mathrm{FC}=$ flavonoid content (mg/g extract); $\mathrm{C}=$ concentration of sample established from the calibration curve $(\mathrm{mg} / \mathrm{L}) ; \mathrm{V}=$ volume of sample solution (L); $\mathrm{M}=$ weight of ethanolic plant extract $(\mathrm{g})$. Total flavonoid content was expressed as mg quercetin equivalent per gram extract (mg QE. $\left.\mathrm{g}^{-1}\right)$.

\section{Antioxidant assay}

Antioxidant activity assay refers to Arung et al. (2006) with slight modifications. Antioxidant activity was determined by decolorization of DPPH solution and carried out using a UV/Vis spectrophotometer at room temperature. The range of concentration of the samples were 12,$5 ; 25 ; 50 ; 100$ and $200 \mathrm{mg} / \mathrm{L}$ (or ppm). One $\mathrm{ml}$ of the sample was added with $2 \mathrm{ml}$ of DPPH $60 \mathrm{mg} / \mathrm{L}$, and incubated at room temperature in the dark for 30 minutes. Absorbance was measured at $523 \mathrm{~nm}$. Quercetin is used as a positive control with concentrations of $2,4,6,8$ and 10 $\mathrm{mg} / \mathrm{L}$. The percentage of inhibition was calculated using the following equation: \% DPPH inhibition $=[(\mathrm{Ab}-$ $\mathrm{As}) / \mathrm{Ab}$ ]. $100 \%$; where $\mathrm{Ab}=$ absorbance of blank sample, As $=$ absorbance of sample.

The absorbance of each sample was measured and calculated to determine the value of inhibition percentage (reduction). Linear regression equation obtained from the scatter plot of extract concentration and inhibition percentage was used to calculate $\mathrm{IC}_{50}$ value. The $\mathrm{IC}_{50}$ value is the concentration of extract required to inhibit $50 \%$ of DPPH free radical. According to Miryanti et al. (2011) states that antioxidant activity is considered extremely high if the value of $\mathrm{IC}_{50}$ is less than $50 \mathrm{ppm}$, high if the value of $\mathrm{IC}_{50}$ is between $50-100 \mathrm{ppm}$, moderate if the value is between $100-150 \mathrm{ppm}$ and low if the value is between $151-200$ ppm.

\section{Data analysis}

The qualitative and quantitative data obtained were analyzed descriptively. Antioxidant activity was grouped according to $\mathrm{IC}_{50}$ criteria, while total phenolic and flavonoids were determined as mean \pm SD. All measurements were done in triplicate.

\section{RESULTS AND DISCUSSION}

\section{Phytochemical screening}

Phytochemical screening was carried out to determine the secondary metabolites in the sample. The result of the phytochemical screening assay can be seen in Table 1.

Phytochemical screening was carried out due to its simplicity, speed, minimum use of equipment and selectivity (Nohong 2009). The result of phytochemical screening shown in Table 1 indicated that $P$. pycnophylla, $P$. glauca, and $S$. palustris contain alkaloid, flavonoid, tannin, saponin, and steroid group, but alkaloid was absent in A. Aureum. The principle of the alkaloid test is the formation of sediment due to ligand replacement. Nitrogen atoms which are alkaloid lone pairs replace iodine ions in Dragendorf and Mayer reagents (Sangi et al. 2008).

All samples containing flavonoids were characterized by the formation of yellow/orange layers in the amyl alcohol layer. Flavonoids have the potential as antioxidants which can prevent the formation of free radicals.

Saponin contains glycosyltransferase acting as polar groups, while steroid and triterpene to function as nonpolar groups. All samples contain saponin. According to Saxena et al. (2013), many saponins are known to be antimicrobial, to inhibit mold, and to protect plants from insect attack.

Based on the results in Table 1, all samples contain condensed tannins. The addition of $\mathrm{FeCl}_{3}$ causes the hydrolyzed tannin to turn into blue while the condensed tannin turns into green. Decolorization occurs because $\mathrm{FeCl}_{3}$ reacts to one of the hydroxyl groups in the tannin (Sangi et al. 2008).

Steroid analysis was based on the ability of the compound to change color with concentrated $\mathrm{H}_{2} \mathrm{SO}_{4}$ in acetic anhydride (Sangi et al. 2008). The results show the formation of a greenish blue ring which means the extract contains steroids.

As far as we know, there is no report about phytochemical screening of $P$. glauca and P. pycnophylla. Study of Khan et al. (2013) showed that ethanol extract $A$. aureum contained alkaloids, glycosides, tannins, flavonoids, and terpenoids. The results of the study differ from Khan (2013) alleged because according to Salim et al. (2016) differences in the place of growth of a species affect the precursors of biosynthesis of secondary metabolites. While methanol extract contained proteins and amino acids, glycosides, steroids, triterpenes, saponins, and flavonoids (Raja and Ravindranadh 2014). Study of Chai (2012) showed that $S$. palustris contains polyphenols, flavonoids, cinnamic acid, and anthocyanins.

Table 1. Phytochemical detected in fern extracts collected from East Kalimantan, Indonesia

\begin{tabular}{|c|c|c|c|c|c|c|c|}
\hline Species & Local name & Part & Alkaloid & Flavonoid & Tanin & Saponin & Steroid/Terpenoid \\
\hline Plagiogyria pycnophylla & Paku atai merah & Leaf & + & + & + & + & + \\
\hline Plagiogyria pycnophylla & Paku atai merah & Rhizome & + & + & + & + & + \\
\hline Plagiogyria glauca & Paku atai putih & Leaf & + & + & + & + & + \\
\hline Acrostichum aureum & Paku laut & Leaf & - & + & + & + & + \\
\hline Stenochlaena palustris & Kelakai & Leaf & + & + & + & + & + \\
\hline
\end{tabular}

Note $:(+)=$ presence; $(-)=$ absence 
Table 3. Total phenolic and flavonoid content in ferns ethanolic extract

\begin{tabular}{lccc}
\hline \multicolumn{1}{c}{ Sample } & Part & $\begin{array}{c}\text { Total Phenolic Content } \\
(\text { mg GAE.g } \text { extract })^{-1}\end{array}$ & $\begin{array}{c}\text { Flavonoid Content } \\
(\text { mg QE.g }\end{array}$ \\
\hline P. pycnophylla & Leaf & $264.0565 \pm 4.0365$ & $114.8439 \pm 1.6012$ \\
P. pycnophylla & Rhizome & $286.9202 \pm 9.4492$ & $127.1995 \pm 0.4558$ \\
P. glauca & Leaf & $83.8114 \pm 8.7162$ & $81.1347 \pm 0.8025$ \\
A. aureum & Leaf & $366.4573 \pm 2.2117$ & $228.6087 \pm 2.2548$ \\
S. palustris & Leaf & $245.3011 \pm 3.2382$ & $166.1779 \pm 4.1420$ \\
\hline
\end{tabular}

Note: The data are averaged \pm SD, $n=3$

Table 2. IC $_{50}$ value and antioxidant activity of fern extracts collected from East Kalimantan

\begin{tabular}{llll}
\hline Sample & Part & IC50 $(\mathbf{p p m})$ & Category \\
\hline P. pycnophylla & Leaf & 124.6806 & Moderate \\
P. pycnophylla & Rhizome & 106.5234 & Moderate \\
P. glauca & Leaf & 995.0497 & No activity \\
A. aureum & Leaf & 29.5303 & Very strong \\
S. palustris & Leaf & 140.7528 & Moderate \\
\hline
\end{tabular}

\section{Total phenolic}

Phenolics, which are secondary metabolites of plants, exhibit remarkable bioactivities. A large body of epidemiological studies has proven the bioactivities of phenolics in both standard compounds and natural extracts: namely, anticancer, anti-inflammatory, and antibacterial activities as well as reducing diabetes, cardiovascular disease, and neurodegenerative disease. Phenolics also display anti-analgesic, anti-allergic, and anti-Alzheimer's properties (Shahidi and Yeo 2018). The results of total phenolic and flavonoid content were presented in Table 3.

Total phenolic has been known to have biological activity as free radical scavengers and antioxidants. Its antioxidant activity is mainly caused by redox properties which act as reducing agents, hydrogen donors and singlet oxygen quenchers (Chandra et al. 2014). Ethanol extract of A. aureum leaves showed the highest phenolic content $\left(366.4573 \pm 2.2117 \mathrm{mg}\right.$ GAE.g $\left.\mathrm{g}^{-1}\right)$ followed by $P$.

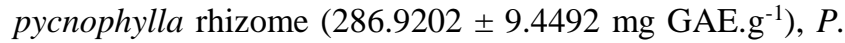
pycnophylla leaves $\left(264.0565 \pm 4,0365 \mathrm{mg}\right.$ GAE.g $\left.{ }^{-1}\right), S$. palustris $\left(245.3011 \pm 3.2382 \mathrm{mg} \mathrm{GAE} . \mathrm{g}^{-1}\right)$ and $P$. glauca $\left(83.8114 \pm 8.7162 \mathrm{mg} \mathrm{GAE} . \mathrm{g}^{-1}\right)$. The results of this study showed that total phenolic content was positively correlated with antioxidant activity. Based on Tables 2 and 3 it can be concluded that the higher the total content of phenol, the antioxidant activity is also getting stronger. Kumar et al. (2014) reported that phenolic compounds as the main contributors to antioxidant activity.

\section{Flavonoid}

Flavonoids are one of the largest natural phenolic compounds and are found in all plants, therefore it is certain that flavonoids are found in every plant extract (Markham 1988). The results in Table 3 showed that $A$. aureum had the highest flavonoid content (228.6087 \pm $2.2548 \mathrm{mg} \mathrm{QE.g}{ }^{-1}$ ), followed by S. palustris (166.1779 \pm $4.1420 \mathrm{mg}$ QE. $\left.{ }^{-1}\right)$, P. pycnophylla rhizome (127.1995 \pm $0.4558 \mathrm{mg}$ QE.g $\left.{ }^{-1}\right)$, P. pycnophylla leaves (114.8439 \pm $\left.1.6012 \mathrm{mg} \mathrm{QE.g}{ }^{-1}\right)$, and P. glauca $(81.1347 \pm 0.8025 \mathrm{mg}$ QE.g $\left.{ }^{-1}\right)$. Generally, phenolics and flavonoids constitute a major group of compounds, which act as main antioxidant (Adesegun et al. 2007). Differences in flavonoid structure and group substitution affect the stability of phenoxyl radicals, thus affecting the antioxidant properties of flavonoids (Wojdyło et al. 2007).

Yao et al. (2010) showed a correlation between antioxidant activity and total flavonoid content and total phenolics in celery. This is in accordance with the results of this study on ferns where A. aureum extract contains the highest total phenolic, and flavonoids and antioxidant activity.

\section{Antioxidant activity}

Antioxidant activity of ethanol extract of several species of ferns was carried out using the DPPH method, and measured using a UV-Vis spectrophotometer. DPPH free radical scavenger method was chosen due to its simplicity, ease, speed, sensitivity and the little amount of samples needed (Marzuki et al. 2012). DPPH, is a stable free radical which possesses purple color will turn to yellow compound when it reacts with antioxidant compounds. In this reaction, antioxidants release electrons to DPPH.

The results in Table 2 show the $\mathrm{IC}_{50}$ value of $A$. aureum extract is $29.5303 \mathrm{ppm}$ which is categorized as a very strong antioxidant. According to Miryanti et al. (2011) $\mathrm{IC}_{50}$ values $<50 \mathrm{ppm}$ for antioxidant was very strong. The $\mathrm{IC}_{50}$ value of quercetin as a positive control is $5.9866 \mathrm{ppm}$ which was also categorized as very strong antioxidant activity. Based on the $\mathrm{IC}_{50}$ value, the extracts of $P$. pycnophylla and $S$. palustris are categorized as moderate antioxidant activity, with $\mathrm{IC}_{50}$ values ranging from 106.5234 - 140.7528, while $P$. glauca extract does not have antioxidant activity based on its IC $_{50}$ value $(995.0497 \mathrm{ppm})$

Antioxidant activity is influenced by total phenol levels and flavonoids. Phenol and flavonoid compounds have a linear contribution to antioxidant activity, so the higher the level the better the antioxidants (Ghasemzadeh and Ghasemzadeh 2011). High levels of total phenolic in the ethanol extract of $A$. aureum are thought to have an important role as antioxidants. Besides phenol and flavonoids, other phenolic components such as tannins, alkaloids and terpenoids (Saxena et al. 2013) also contribute as antioxidants.

Based on research, ethanol extract of A. aureum has the highest levels of total phenolic, flavonoids with very strong 
antioxidant activity. There is a positive correlation between levels of total phenolic, flavonoids with antioxidant activity. Further research needs to be done to isolate active compounds of $A$. aureum as antioxidants.

\section{ACKNOWLEDGEMENTS}

The authors were grateful to Institute for Research and Community Services of Akademi Farmasi Samarinda and the Directorate General of Strengthening Research and Development, Ministry of Research, Technology, and Higher Education of Republic of Indonesia for the cooperation provided. This research was funded through the Collaborative Research Inter-University Scheme with Contract No.: 560/KONTRAK-PENELITIAN/ K11/KM/2018.

\section{REFERENCES}

Adesegun SA, Fajan A, Orabueze CI, Coker HAB. 2007. Evaluation of antioxidant properties of Phaulopsis fascisepala C.B.Cl. (Acanthaceae). Adv Access Publ 6 (2): 227-231.

Alfian R, Susanti H. 2012. Determination of total phenolic content of methanol extract of red roselle petals (Hibiscus sabdariffa Linn.) with growth variations by spectrophotometric method. Sci J Pharm 2 (1): 73-80.

Arung ET, Shimizu K, Kondo R. 2006. Inhibitory effect of isoprenoidsubstituted flavonoids isolated from Artocarpus heterophyllus on melanin biosynthesis. Planta Med 72 (9): 847-850.

Bajalan I, Zand M, Goodarzi M, Darabi M. 2017. Antioxidant activity and total phenolic and flavonoid content of the extract and chemica composition of the essential oil of Eremostachys laciniata collected from Zagros. Asian Pac J Trop Biomed 7 (2): 144-146.

Chai TT, Panirchellvum E, Ong HC, Wong FC. 2012. Phenolic contents and antioxidant properties of Stenochlaena palustris, an edible medicinal fern. Bot Stud 53 (4): 439-446.

Chandra S, Khan S, Avula B, Lata H, Yang MH, ElSohly MA, Khan IA 2014. Assessment of total phenolic and flavonoid content, antioxidant properties, and yield of aeroponically and conventionally grown leafy vegetables and fruit crops: a comparative study. Evid-Based Compl Altern Med 2014: 253875, 9 pages. DOI: 10.1155/2014/253875.

Cross CE., Vliet AV and O'Neil C. 1994. Reactive oxygen species and the lung. Lancet 344: 930-933.

Ghasemzadeh A, Ghasemzadeh N. 2011. Flavonoids and phenolic acids: Role and biochemical activity in plants and human. J Med Plants Res 5 (31): 6697-6703.

Harborne JB. 1987. Method of phytochemical guidance in modern ways of analyzing plants. Translated by Padmawinata, K. ITB-Press, Bandung. [Indonesian]
Imaniar R, Pujiastuti, Murdiyah S. 2017. Identification of diversity of ferns in the waterfall area of blue cotton in the district of Pronojiwo, Lumajang district, and its use as a booklet. J Biol Educ 6 (3): 337345.

Khan SA, Hossain MA, Panthi S, Asadujjaman A, Hossin A. 2013. Assessment of antioxidant and analgesic activity of Acrostichum aureum Linn. (Family- Pteridaceae). Pharmacol Online 1: 166-171.

Kumar S, Sandhir R, Ojha S. 2014. Evaluation of antioxidant activity and total phenol in different varieties of Lantana camara leaves. BioMed Central Research Notes 7: 560. DOI: 10.1186/1756-0500-7-560.

Markham, 1988. How to Identify Flavonoids. ITB Publishing, Bandung. [Indonesian]

Marjoni R. 2016. Phytochemical Basics. CV. Trans Info Media, Jakarta. [Indonesian]

Marzuki A, Hasyim N, Sartini, Sapri. 2012. Antioxidant activity test of stem wood ethyl acetate extract of Banyuru Sulawesi (Pterospermum celebicum Miq.) with DPPH (2,2-diphenyl-1-picrylhydrazyl) free radical scavenging method. Pharm Pharmacol Mag 16 (3): 147-150.

Miryanti A, Sapei L, Budiono K, and Indra S. 2011. Extraction of antioxidants from the skin of mangosteen fruit (Garcinia mangostana L.). University of Catholic Parahyangan, Bandung. [Indonesian]

Nohong. 2009. Phytochemical screening of Ophiopogon jaburan Lodd plant from Kolaka district, Southeast Sulawesi province. J Learning Sci 5 (2): 172-178.

Phaniendra A, Jestadi DB, and Periyasamy L. 2015. Free radicals: Properties, sources, targets, and their implication in various diseases. Indian J Clin Biochem. 30 (1): 11-26.

Raja S, Ravindranadh K. 2014. Preliminary phytochemical screening of different solvent extracts of whole plant of Acrostichum aureum. World J Pharm Sci 2 (12): 1753-1759.

Ridianingsih DS, Pujiastuti, Hariani SA. 2017. Inventory of ferns (Pteridophyta) in Rowobendo-Ngagelan post, Alas Purwo National Park, Banyuwangi district. Bioexperiment 3 (2): 20-30.

Salim M, Yahya, Sitorus H, Ni'mah T, Marini. 2016. The relation of nutrient soil content to the secondary metabolites production in duku plant (Lansium domesticum Corr var duku) and it's larvacide potential. Jurnal Vektor Penyakit 10 (1): 11-18.

Sangi M, Runtuwene MRJ, Simbala HEI, Makang VMA 2008 Phytochemical analysis of medicinal plants in North Minahasa regency. Chem Prog1 (1): 47-53.

Saxena M, Saxena J, Nema R, Singh D, and Gupta A. 2013. Phytochemistry of medicinal plants. J Pharmacog Phytochem 1 (6): 168-182.

Sayuti K, Yenrina R. 2015. Natural and Synthetic Antioxidants. Andalas University Press, Padang.

Shahidi F, Yeo JD. 2018. Bioactivities of Phenolics by Focusing on Suppression of Chronic Diseases: A Review. Intl J Mol Sci 19 (6): 1573.

Wang X, Wang M, Cao J, Wu Y, Xiao J, Wang Q. 2017. Analysis of flavonoids and antioxidants in extracts of ferns from Tianmu Mountain in Zhejiang Province (China). Ind Crops Prod 97: 137-145.

Wojdyło A, Oszmianski J and Czemerys R. Antioxidant activity and phenolic compounds in 32 selected herbs. Food Chem 105 (3): 940949.

Yao Y, Sang W, Zhou M and Ren G. 2010. Phenolic composition and antioxidant activities of 11 celery cultivars. J Food Sci 75 (1): C9-13. 